\title{
Reconfiguring Food Systems Governance: The UNFSS and the Battle Over Authority and Legitimacy
}

\author{
Matthew C. Canfield ${ }^{1} \cdot$ Jessica Duncan ${ }^{2} \cdot$ Priscilla Claeys $^{3}$
}

Published online: 13 October 2021

(c) Society for International Development 2021

\begin{abstract}
The UN Food Systems Summit was an ambitious and hotly contested event that brought competing approaches to global food governance into relief. In this article, we unpack the rival visions that circulate around how food systems should be governed, focusing on two issues that we feel are at the heart of these divergences: authority and legitimacy. We illustrate how both corporate-philanthropic and food sovereignty networks are struggling to establish epistemic authority of food systems as well as produce legitimacy through very different approaches to participation and accountability.
\end{abstract}

Keywords Multilateralism · Multi-stakeholderism · UN Committee on World Food Security

There are eight years left to reach the Sustainable Development Goals (SDGs). Food systems lie at the heart of many of these goals when it comes to lifting people out of poverty, ending hunger, enabling life on the land and mitigating climate change. Yet all the indicators suggest the food systems are failing. When it comes to SDG2, hunger has been increasing, a trend that started before the COVID-19 pandemic (FAO et al. 2020). When it comes to SDG 13, climate action, food systems are one of the largest contributors to global greenhouse gas emissions and the loss of biodiversity. Without addressing the emissions from industrial food systems, the world is unlikely to meet the target of limiting emissions to 1.5-2 degrees Celsius (Clark et al. 2020). It is in this context that the UN Secretary-General announced the organization of a UN Food Systems Summit (UNFSS) as part of the Decade of Action to raise awareness and push forward the SDGs. The website of the Summit projects a great deal of optimism: 'We can build a just and resilient world where no one is left behind'; 'Transforming food systems is within reach'.

Matthew C. Canfield

m.c.canfield@law.leidenuniv.nl

1 Van Vollenhoven Institute, Leiden Law School, Leiden, The Netherlands

2 Rural Sociology Group, Wageningen University, Wageningen, The Netherlands

3 Centre for Agroecology, Water, and Resilience, Coventry University, Coventry, UK
The elevation of food systems to such a high-profile event is indeed cause for hope. When it comes to governance, academics and civil society organizations have long sought to shift away from the dominant focus on food production and productivist solutions, calling instead for greater integration of the diverse elements and activities connecting production, processing, distribution, preparation, consumption and disposal of food. They have also called for a broader consideration of the social, economic, cultural and ecological dimensions of food, along with addressing issues of power, agency and rights (HLPE $2020 \mathrm{XV}$ ).

A food systems framing can do just that. If understood in its multidimensionality and complexity, food systems approaches have the potential to combine and serve multiple social-ecological objectives, such as the protection and regeneration of nature, health and wellbeing, as well as the defense of livelihoods, culture and knowledge, labour and social relations. Yet the rise of food systems discourse has generated heated debates on the conceptualization and implications of the term, attesting to the fact that food systems are fundamentally shaped by relations of power.

Although the leaders of the UNFSS sought to evade issues of power by calling the UNFSS a 'People's Summit' and an 'Action Summit', they were in fact deeply imbricated within them. Having emerged out of a partnership between the United Nations and the World Economic Forum, the very first action of the UNFSS process was the appointment of Dr. Agnes Kalibata, the President of the Alliance for a Green Revolution in Africa (AGRA), largely funded by the Bill \& 
Melinda Gates Foundation. Actors in the global food sovereignty movement reacted strongly to the appointment of Dr. Kalibata, which was a sign that the UNFSS was being shaped by a shadow network of global philanthropies, multinational corporations, and powerful states. In the following months, food sovereignty actors deepened their analysis and articulated a critique of the FSS around five key points, leading them to call for a boycott. These five points included: 1) that the decision-making structure of the UNFSS lacked clarity, transparency and accountability mechanisms; 2) that it was not firmly grounded in a human rights framework, despite using a rights rhetoric; 3 ) that it was co-opting some of the transformation narratives used by food sovereignty movements, such as agroecology, resilience and Indigenous knowledge; 4) that it relied on a narrow view of science and knowledge to push for technology-driven food systems development, digitalization and financialization; 5) that was dominated by corporate interests; and finally, 6) that it undermined existing democratic governance structures and multilateral public institutions such as the UN Committee on World Food Security (CFS), which has mechanisms in place to facilitate the participation of those most affected by food insecurity. ${ }^{1}$

In bypassing the CFS, which was reformed to facilitate inclusive political debates over food security governance, the UNFSS raised concerns that those leading the Summit were seeking to redesign global food governance in ways that favored their interests. The Summit therefore generated intense political struggles, not only over the future of our food systems but also over global food systems governance. Food systems governance refers to the institutions, actors, rules, and norms that shape how food is produced, distributed, and accessed across borders (Margulis and Duncan 2016). It also encompasses the processes by which diverse actors within food systems are incorporated into decision and policymaking at different levels. Food systems governance is constituted by competing and overlapping networks composed of actors including states, civil society, philanthropies and transnational corporations who draw on vastly different resources in exercising power (Canfield 2021). Through the UNFSS, rival actors consolidated their networks and struggled to embed their own visions and interests into global food systems governance.

In this article, we place the UNFSS in historical context. By comparing it with previous food summits, we explore how the UNFSS is reshaping global food systems governance. We also unpack the divergent visions that circulate around how food systems should be governed, focusing

\footnotetext{
${ }^{1}$ Civil Society and Indigenous Peoples Mechanism. What's wrong with the Food Systems Summit? https://www.csm4cfs.org/wp-conte nt/uploads/2021/07/Common-analysis-EN.pdf.
}

on two issues that we feel are at the heart of these divergences: authority and legitimacy. We analyze the ways in which competing networks of actors are struggling to set the terms for authority and legitimacy in the UNFSS and beyond. In doing so, we excavate the latent vision of governance embedded in the Summit, and the contemporary mechanisms and debates through which global food governance is being constructed and contested.

\section{Summits and the Reconstruction of Global Food Governance}

UN summits have historically played a key role in galvanizing action in response to global food crises as well as reconfiguring existing global governance arrangements. Past summits in 1974, 1996, 2002, and 2009, each reconfigured the institutional architecture dedicated to addressing global hunger as well as the epistemic and normative frameworks through which global food and agricultural policy was then organized. Though space does not permit us to review the unique context in which each Summit emerged, all of the Summits were shaped by intense clashes over power.

Prior to the 2021 Summit, UN food summits were organized as multilateral events. Authority was vested in nationstates. Powerful states continuously leveraged the fragmented landscape of global food governance and tensions between international institutions to promote their interests (McKeon 2015). In the 1990s and 2000s, the actors involved in global governance began to shift. As states pursued privatization, deregulation, and market liberalization, power began to accrue in other actors, such as transnational corporations. In turn, transnational advocacy networks and agrarian movements formed to challenge the power of large agroexporting states and promote more effective and equitable multilateral governance over food and agriculture. Throughout the past three decades, networks of social movements and non-governmental organizations have mobilized within and outside these global institutions to address the structural causes of hunger ranging from the long-term effects of colonialism to agro-industrial development initiatives to neoliberal trade regimes.

Significant changes occurred during the 2009 World Summit on Food Security (WSFS) that set the stage for the 2021 UNFSS. Organized in the midst of overlapping food and financial crises, the 2009 WSFS became a battleground in which competing networks sought to leverage different international institutions and mechanisms to respond to the crisis (Duncan 2015). A network of powerful agro-exporting states and transnational corporations sought to evade responsibility for the crises by exploiting the fragmented food governance landscape. Transnational agrarian movements, meanwhile, federated through the International Planning 
Committee for Food Sovereignty (IPC) organized a countersummit, the People's Food Sovereignty Forum, to challenge the inaction of powerful states and international institutions, and denounce the human rights abuses of transnational corporations. By organizing a counter-summit outside of the WSFS, as civil society organizations had done during previous summits, they worked to reinforce their shared vision, alliances and promote grassroots solutions grounded in food sovereignty, the right to food and increasingly, agroecology. They successfully took advantage of the political opportunity opened up by the global food crisis of 2007-08 to push for the reform of the CFS and advance their vision of democratic and inclusive multilateralism.

Through the reform, the CFS became a laboratory for experimenting and designing a new format for global food security governance premised on: evidence-based decisionmaking and participation/inclusivity. The reformed CFS included a science-policy interface, the High-Level Panel of Experts (HLPE), as well as a multi-stakeholder structure that vested decision-making power in states but enabled different stakeholders (civil society, private sector, philanthropies, the scientific community and international institutions) to participate and collectively shape decisions. Within that structure, civil society secured the right to autonomously self-organize its participation so as to foster diversity, prioritize the voice of those most affected, and speak with one voice (Brem-Wilson 2015; McKeon 2015; Claeys and Duncan 2019a). As the 'foremost inclusive international and intergovernmental platform for all stakeholders to work together to ensure food security and nutrition for all', the CFS has significantly transformed the conditions through which authority and legitimacy were historically assembled in global food governance. The process for developing recommendations includes comprehensive knowledge assessments by the HLPE and inclusive negotiations that contribute to the authority of the CFS. The inclusion of the voices of those most affected by food insecurity who have the capacity to not only bring local-level issues to the global stage, but also to bring CFS policy recommendations and guidelines to the local level, has also endowed the CFS with significant legitimacy. Together these features have made the CFS an appealing new governance model.

Over the last two decades transnational social movements have committed to build, maintain and improve the Civil Society and Indigenous Peoples Mechanism (CSM) and have productively engaged with states and other actors in the CFS. As a result, they have grown increasingly influential in promoting the human right to food and nutrition, agroecology, women's rights, peasants' rights and food sovereignty (Claeys 2015). Constituencies most affected by hunger and food insecurity self-organized in the CSM and managed to speak with one voice to influence CFS debates. They participated in generating a number of flagship policy outputs through consensus, the most recognized one being its Voluntary Guidelines on the Responsible Governance of Tenure of Land, Fisheries and Forests in the Context of National Food Security. In 2017, after years of advocacy by the CSM, the CFS began its own political process to develop policy recommendations on agroecology (Anderson and Maughan 2021).

Complementary struggles for the participation of affected constituencies in food governance preceded and developed alongside the reform of the CFS. The transnational agrarian movement La Vía Campesina (LVC), representing over 200 million small-scale food producers, signed a partnership agreement with FAO in 2013 which focused on seeds and agroecology. The IPC, a network bringing together various agrarian movements, pushed for the FAO to adopt an agroecological agenda and helped to facilitate a series of international and regional symposia on agroecology organized by FAO between 2014 and 2018. In the Human Rights Council, LVC succeeded in negotiating a new international legal instrument recognizing new rights for peasants between 2012 and 2018. The UN Declaration on the Rights of Peasants and other People working in Rural Areas was subsequently adopted by the UN General Assembly in 2018 (Claeys and Edelman 2019).

All of these efforts reflect significant advances made by social movements in bringing the voices of those most affected by food insecurity and malnutrition into international policymaking arenas. Through their participation, they successfully challenged the hegemonic productivist narrative that had dominated global food governance since the 1960s, demanding that their voices, experiences and knowledge be at the center of food systems governance, so as to ensure the realization of their rights. Under the former Director General of the FAO, José Graziano da Silva, there was growing consensus that food systems needed to be fundamentally transformed to address the challenge of hunger, unhealthy diets, and the contribution of food systems to climate change. In his final speech to the FAO Conference, da Silva proclaimed that he was 'increasingly convinced...that conventional policies aimed at keeping food prices low for consumers are contributing to perpetrate rural poverty and drive internal and external migration, and it is not helping to bring hunger numbers down. It also contributes to unhealthy eating and leads to gross under-investment in sustainable natural resources management'.

However, the success of transnational social movements and civil society organizations in shaping global food governance also suffered a series of blows and backlash. In 2018 and 2019, the United States' Ambassador to the Rome-Based

\footnotetext{
2 Da Silva, José Graziano. 2019. 41st Session of the FAO's Conference. http://www.fao.org/director-general/former-dg/da-silva/my-state ments/detail/en/c/1200387/.
} 
Agencies rebuked the Food and Agriculture Organization for supporting agroecology and a powerful network of global philanthropies and transnational agribusiness firms mobilized to challenge the narrative of food systems transformation, which had been increasingly aligned with the agroecological vision offered by peasant movements. In 2020, da Silva's replacement, Qu Dongyu, signed a partnership with CropLife, a pesticide company, signaling internal divisions within FAO but also pressures from powerful networks. CFS negotiations on agroecology as well as food systems and nutrition throughout 2020 and 2021 proved very difficult and disappointing. As powerful actors organized to challenge the political space created by food sovereignty movements across UN spaces, they drew on the same strategies that actors have long drawn on when they have sought to reset global food governance: a global summit.

\section{Structure and Leadership of the UNFSS}

The UNFSS was convened and organized by the UN Secretariat in New York and not by the FAO. A key theme that pervades the history of Summits is the competition between Rome and New York and the way that actors have leveraged the fragmented landscape of global food governance and tensions between institutions to promote their interests (Clapp and Murphy 2013; Margulis 2017). Powerful networks have consistently sought to circumnavigate the FAO when they adjudged that New York-based institutions would provide them with greater leverage. In 1974, for example, the UN Secretariat insisted on being the organizer of the World Food Conference, which led to the decentralization and fragmentation of global food governance, as well the founding of the dysfunctional and ultimately abandoned World Food Council (Shaw 2007). During the 2007-08 global food and financial crises, these dynamics also threatened to derail a substantive response to the crisis. Powerful actors, particularly the G8, once again sought to route food systems governance through the UN Secretariat through the deployment of a High-Level Task Force on the Global Food Security Crisis in order to maintain the fragmented architecture of global food governance (Duncan 2015). Yet due largely to the mobilization of civil society and states in the Global South, the FAO successfully consolidated its authority over global food security governance through the reformed CFS. In parallel, powerful actors have continued to push for food systems governance through multi-stakeholder initiatives such as the Scaling Up Nutrition Movement, the Global Alliance for Improved Nutrition, as well as New York-based forums such as the High-Level Political Forum on Sustainable Development.

The UNFSS was the direct result of a strategic partnership that the UN Secretariat signed with the World Economic
Forum (WEF) in July 2019. For the past two decades, the UN Secretariat, along with UN bodies including the FAO and Human Rights Council, have developed increasingly friendly and formal relationships with transnational corporations in response to dwindling financial resources and political authority (Bruno and Karliner 2002; Gleckman 2018). In turn, the corporate sector has moved to partner with the United Nations to shore up its legitimacy and influence the regulatory contexts in which it operates. Indeed, since the 2007-08 global food and financial crises, the WEF has pursued a closer relationship with the UN in an express bid to redesign global governance in ways that entrench the corporate sector through market-oriented forms of governance (McMichael, this issue), a vision shared by other powerful actors such as the Bill \& Melinda Gates Foundation. By turning to the UN Secretariat, rather than the FAO, this powerful group of actors was able to set the agenda for the Summit and ensure that the leadership of the Summit was drawn from its networks.

The leadership of the Summit was selected by the UN Deputy Secretary-General. It was given the prerogative to frame the issues discussed, design the structure of the Summit, hire staff, and invite experts to participate in the UNFSS. The Summit's two most important leaders, the UN Secretary-General's Special Envoy and the Chair of the Scientific Committee were both deeply embedded in the corporate-philanthropic network that has promoted market-based and technology-driven approaches to food systems. The former, Dr. Agnes Kalibata, was simultaneously the President of the Alliance for a Green Revolution in Africa (AGRA) funded by the Bill \& Melinda Gates Foundation. The latter, Joachim von Braun, served as a member of the World Economic Forum's Council on Food Security from 2008-2011 and continues to serve simultaneously as the co-Chair of the Programs Committee of AGRA. Together, Kalibata and von Braun developed a structure and process for the Summit that bypassed existing institutions.

The UNFSS was rolled out over a period of almost two years from 2019-2021. It deployed five 'Action Tracks' that each focused on specific dimensions of food systems transformation and established several groups that were focused on the overall governance and promotion of the Summit. Three features of the Summit diverged significantly from past UN food summits.

First, the Summit adopted a multi-stakeholder structure. Previous Summits have been organized through multilateral institutions of the UN and have respected the normative framework of public international law through which the UN has generally operated. In these previous Summits, states were the primary participants, and the emphasis was on their commitments to take action and follow up on collectively made decisions. By contrast, the UNFSS was structured as a multi-stakeholder initiative. Multi-stakeholder initiatives 
are aimed at including 'all affected stakeholders' in decision-making, but they often take different forms. Some are focused on developing policy, others are concerned with standards for particular products and technologies, and still others are convened around specific projects (Gleckman 2018: 17-26). The UNFSS conformed to none of these more common uses of multi-stakeholder governance. Instead, as described below, the outcomes and goals of the Summit, as well as the decision-making process were never clearly defined.

Second, though it was announced before the COVID-19 pandemic, the entire Summit took place within the midst of the pandemic. This transformed the conditions of the Summit, by precipitating a crisis in the midst of conference organizing and shifting the modalities of participation. Unlike other summits that have centered on a few days of face-to-face meetings between member states with other stakeholders as observers, the UNFSS included multiple multi-stakeholder workstreams and 'Dialogues' that took place almost entirely virtually in late 2020 and throughout 2021. The virtual format of the Summit activities constrained the participatory capacity of the Summit not only due to inequitable access to information and communications technologies, but also inequitable access to vaccines and COVID-treatments. It turned the Summit into a massive media and outreach machine set to convince the world it was inclusive and participatory. It also meant that food sovereignty movement actors had to virtually organize their counter-summit events. The COVID-19 pandemic also further exacerbated geopolitical tensions, particularly between China and the United States. In the midst of these global struggles over power, the UNFSS stayed strangely silent on the pandemic despite repeated calls from civil society and the Special Rapporteur on the Right to Food to add the impacts of COVID on food security on the UNFSS agenda.

Finally, the Summit included a Scientific Group that helped to set the agenda for the Summit, by establishing the terms of the debate as well as constructing the frame through which food systems transformation was evaluated. As we explore below, the weight given to the Scientific Group was unprecedented. The Scientific Group developed a mechanistic definition of food systems, which maintained many of the assumptions of the Western productivist approach to food and agriculture (Montenegro de Wit et al. this issue). Moreover, the Scientific Group was able to frame each of the Action Tracks through an agenda-setting paper. The 'Pre-Summit' organized by Special Envoy was also preceded one week earlier by 'Science Days', a threeday event that included panels on a wide range of topics that explore the role and potential of 'science, technology, and innovation' for transforming food systems. The narrow lens through which the Scientific Group approached food systems combined with its agenda-setting role significantly influenced the process and outcomes of the Summit.

These features shaped the political terrain through which actors and networks engaged in the Summit. Whereas the multilateral framework through which global food governance has long located authority in the nation-state and hinged legitimacy on states' fulfillment of their duties and obligations under human rights, in blurring the boundaries between states, corporations, and civil society, the Summit reconstituted the terms through which authority and legitimacy are constituted in global food governance.

\section{Re-establishing Epistemic Authority Over Food Systems}

The signal distinction between the UNFSS and past global summits was its focus on food systems. This 'problematization' of food and agriculture diverged from the dominant problematic through which hunger and malnutrition have been understood, which is as a result of inadequate production (McKeon 2015). The concept and framework of food systems has been developed over the past three decades by researchers and civil society actors to promote a more holistic approach to food production and provisioning (Kneen 1989; Blay-Palmer 2012; Béné et al. 2019). Over the past ten years, the concept of food systems has been elaborated in the CFS, particularly since the HLPE report on Food Losses and Waste in the Context of Sustainable Food Systems in 2014. Through the CSM, transnational social movements and civil society actors have strategically endorsed the concept of food systems to advocate for a holistic, rights-based and gender transformative food systems approach to governance, notably in discussions around nutrition (Recine et al. 2021). Although food systems is not a novel concept in food governance, its mobilization as the dominant framing for the Summit opened up a new terrain of epistemic conflict in which competing networks are struggling to claim authority based on their knowledge and expertise of food systems.

Scholars of global governance have long emphasized the importance of knowledge in establishing authority within governance. Peter Hass illuminated the role played by 'epistemic communities', networks of experts that can shape how problems are perceived and the best ways to address them (Haas 1992; 2015). Ole Jacob Sending (2015) has further argued that authority within global governance is constructed by establishing epistemic authority over governance fields-social spaces of contestation in which competing actors draw on different symbolic and material resources in a struggle to establish the meaning and stakes of the object of governance (Sending 2015: 22). While food systems have been introduced as an object of governance on local and regional levels such as through local food policy councils 
and other (Brons and Hospes 2016; Kennedy and Liljeblad 2016; Andrée et al. 2019), the UNFSS marked the ascension of this concept as the dominant new framing for global food governance. A key goal of the UNFSS, according to the Scientific Group was to develop a standard definition of food systems (Von Braun et al. 2021b).

Since civil society organizations and social movements have been agitating for this expanded systems framework in addressing food, the introduction of this frame at the global level generated significant competition among different epistemic communities and networks. These networks embraced different forms of knowledge, emphasized different aspects of governance, and drew on different resources. The key network that sought to define food systems during the Summit is the Scientific Group, which the Deputy Secretary-General tasked with 'ensuring the Summit brings to bear the foremost scientific evidence and helps expand the base of shared knowledge about experiences, approaches, and tools for driving sustainable food systems that will inform the future'. ${ }^{3}$ The Deputy Secretary-General's selection of Joachim von Braun, an agricultural economist, offers insights into the epistemic and political networks that influenced the Summit. Von Braun, as described above, is deeply enmeshed in corporate philanthropic networks. Moreover, he also has a specific vision for global food governance that he has promoted through publications and networks prior to the Summit (Clapp et al. 2021). Von Braun was tasked with selecting the rest of the 25-member Scientific Group.

The Scientific Group drew on limited forms of knowledge from the natural sciences and economics in defining food systems governance and transformation. This is reflected in the Group's composition, which included 20 natural scientists and 9 economists, with no representation from the other social sciences or other disciplines. In doing so, it framed food systems transformation primarily through the framework of innovation, emphasizing the need for technological and policy innovations based in science, while evading the structural issues that drive many of the issues underpinning food systems (Fakhri 2021). Moreover, the Scientific Group suggested that science should play the ultimate role of arbitrating which solutions should be promoted to improve food systems.

The Scientific Group has sought to institutionalize its authority by calling for a Science-Policy Interface (SPI) that will continue to provide scientific advice to guide food systems transformation (Fears and Canales 2021). Other scientists have challenged the limited understanding of science in both the Scientific Group and the proposed SPI given the potential for the SPI to both entrench a perspective that favor particular interests and its lack of connection to relevant policy bodies (Montenegro de Wit et al. 2021; Turnhout et al. 2021). Nevertheless, the leaders of the Scientific Group continue to promote their proposal (von Braun et al. 2021a).

The Scientific Group of the Summit may play a significant role in shaping food systems in ways that are amenable to the corporate-philanthropic network. However, social movements composed of small-scale food producers (who continue to be the primary food producers) draw on their own symbolic resources to challenge the frames of knowledge promoted by the Summit. Social movements have drawn on agroecology as an alternative to the narrow forms of specialized knowledge promoted by the Scientific Group. Agroecology is a transdisciplinary science, practice, and social movement that draws from a 'dialogue of knowledges' (dialogo de sabares) between indigenous forms of knowledge and Western science (Wezel et al. 2009; MartínezTorres and Rosset 2014). This expansive and egalitarian approach to knowledge claims does not privilege particular kinds of 'innovations' or technologies, but requires solutions to problems rooted in the social, ecological, and economic context of peoples.

The HLPE of the CFS has also sought to defend its own role as the primary Science-Policy Interface body (Clapp et al. 2021). The CFS takes a pluralist approach to knowledge that not only includes a variety of different forms of scientific expertise, but also enables stakeholders of the CFS to nominate experts to participate in HLPE's scientific reviews.

As the Summit opens a new space of epistemic struggle over the governance of food systems, each of these actors and institutions are deploying different and unequal resources in seeking to assert authority over this emerging governance object. While these epistemic debates are unlikely to be resolved anytime soon, the pursuit of establishing a new SPI for food systems by the leadership of the Scientific Group has generated significant polarization among academics, activists, and policymakers. Those concerned are worried that a new SPI would institutionalize the leadership's narrow vision of science, technology, and innovation; would lack a strong grounding and connection to policymaking process; and, would be designed to bypass the HLPE and the CFS. Despite ongoing commitments by the UN Secretariat that they will pursue no new structures of governance as a result of the Summit, the leadership of the Scientific Group has nonetheless relentlessly promoted the creation of a new SPI.

3 Terms of Reference of the Scientific Group. 30 March 2020. https:// sc-fss2021.org/wp-content/uploads/2020/11/Terms_of_Reference_ web.pdf. 


\section{Reconfiguring Legitimacy in Global Food Governance}

The UNFSS has not only engendered an epistemic struggle over food systems governance, it has also produced new struggles over how legitimacy is assessed. Legitimacy is the perceived right to take decisions and make rules and the belief and perception that these are exercised appropriately (Suchman 1995). There are significant challenges in assessing the legitimacy of global governance because, as Jongen and Scholte (2021) note, there are a variety of different actors who perform different functions and who may assess legitimacy based on different terms. The food systems framing signals the importance of connecting fields of global governance (climate, trade, finance, agriculture, investment) that have been hitherto distinct, so as to address siloed decision-making processes across various governance arenas. Yet it also enables the incorporation of new actors that hitherto may not have been deemed legitimate, such as corporations and philanthropies. As multi-stakeholderism is now facilitating the incorporation of all of these actors into global governance, they are struggling to shape the terms by which food systems governance is deemed legitimate. In what follows we consider how legitimacy is being (re) configured through the Summit. We focus on two dimensions of legitimacy that competing networks are struggling to influence: participation and accountability.

\section{Participation in Global Food Governance}

Participation in policymaking has been referred to as the new orthodoxy (Baiocchi and Ganuza 2016; Henkel and Stirrat 2001: 168). Acknowledgement of the complexity of many global challenges, coupled with concerns around democratic deficits, has opened up opportunities for greater participation of non-state actors in policy and governance processes. In this way, participation is emerging as a key dimension through which legitimacy is assessed in global governance. Yet, while participation has the potential to deliver real benefits, it remains problematic and contested, in theory as much as practice (Parfitt 2004: 538). When participation is viewed as a means, the power relations between those at the grassroots and decision-makers are left largely untouched. In turn, objectives, goals and targets remain defined by traditional authorities (Duncan 2015: 43; Turnhout et al. 2021).

In the UNFSS, participation is clearly a key means through which the Summit leadership seeks to claim legitimacy. They describe the UNFSS as a 'People's Summit' and their combined use of dialogues, action tracks, and a comprehensive online platform suggests an unprecedented effort to engage people from all over the world. In a statement posted on the website of the UNFSS, the Special Envoy wrote:

It is a pinnacle moment of the 18-month journey of the People's Summit that brought together people across the world who had a fierce determination to join us in our ambition to create the change we need for more inclusive and sustainable food systems. More than 1000 Dialogues took place across 145 countries where people raised awareness of the challenges faced not only at a local level, but globally as well. The latest science and evidence deepened our knowledge of the problems we must solve. And through public fora, surveys and an online community, more than 2,500 ideas, 52 solution clusters surfaced through the diligent and hard work of thousands engaged in the Summit's Action Tracks, Levers of Change, Scientific Group and Constituency Groups (Kalibata 2021).

The scale is indeed impressive. Yet, behind the numbers, it remains unclear who participated, how their contributions were processed and how their engagement influenced the Summit, if at all. In addition, such widespread participatory processes may at first seem compelling, but they can also be contradictory and may actually de-legitimize governance processes. The approach to participation promoted by the leaders of the UNFSS through its multi-stakeholder architecture reflects what is often referred to as the 'all affected principle.' This principle states that 'All who are affected by a decision should have a right to participate into making it' (Lagerspetz 2015). The UNFSS has sought to open up participation to any persons and organizations that wish to contribute. While the UNFSS has sought to limit the direct participation of corporations, they are not precluded from participation through trade associations and other organizations that represent their interests such as the World Economic Forum and the World Business Council for Sustainable Development.

On a basic level, the all-affected principle is problematic because it fails to account for relations of power and influence. Actors who are more organized or have more resources are able to dominate participatory processes. It also ignores that not all people are affected equally, and not everyone has contributed to the problems equally. It further fails to provide structures for the organization or participation of collectives of people, which has been key in other food governance spaces for ensuring more equitable and representative participation and securing the rights of those most marginalized to speak (Duncan and Claeys 2018). Thus, by embracing the all-affected principle, the UNFSS has simultaneously avoided designing mechanisms to limit the over inclusion of dominant actors, and/or to prioritize the voices of those most affected by food insecurity. 
Social movements and civil society organizations have rejected the logic of the all-affected principle to advance instead the 'most-affected principle.' As discussed above in relation to civil society participation in the CFS, the normative force of global governance outputs, such as CFS policy guidelines, derive their power, legitimacy and impact, in part from civil society participation. In developing this principle, social movements have worked to categorize and prioritize those who are most-affected by food insecurity and malnutrition. These groups include peasants, small-scale food producers, food-chain workers, fisherfolk, pastoralists and the urban poor, as well as women and youth. The most-affected principle was first developed through trial and error in the autonomous practices of social movements and was taken up in the 2009 reform of the CFS. It has been reinforced through the autonomous CSM. This principle, when applied, can usefully re-politicize governance spaces (Duncan and Claeys 2018). Using tools such as constituencies and quotas, this approach has proven effective in supporting alliance building and enabling various actors to speak with one voice in governance arenas, while respecting diversity. It has also supported direct representation in policymaking spaces (Claeys and Duncan 2019b).

While social movements have developed their own approaches to participation, they have also challenged the 'all-affected principle' inherent in the UNFSS by drawing on the framework of human rights. Over the past twenty years, various UN institutions have elaborated the normative framework of the right to food (Narula 2010; Claeys 2015). In 2004, member states of the FAO endorsed the Voluntary Guidelines to support the Progressive Realization of the Right to Food, which elaborated a participatory framework through which governance should be organized. Over time, the FAO has further elaborated the meaning of participation in the context of rights-based approaches to food governance, clarifying that participation should aim to facilitate the voices of those most marginalized in governance processes. Given the UNFSS' embrace of the 'all-affected principle' and the absence of collective governmental negotiation and decision-making, the CSM has challenged the UNFSS as a 'non-normative process with an illegitimate governance structure' in their counter-mobilization during the 'PreSummit' of the UNFSS in July $2021 .{ }^{4}$ As constituencies primarily affected by hunger they insist that they are not stakeholders, but rather rights-holders whose voice governments have a duty to meaningfully incorporate.

\footnotetext{
${ }^{4}$ Declaration of the People's counter-mobilization to transform corporate food systems. 2021.

https://www.csm4cfs.org/thousands-mobilize-to-call-for-food-syste ms-that-empower-people-not-companies/.
}

\section{Accountability in Global Food Governance}

Accountability is the second dimension of legitimacy that is upended by the multi-stakeholder model. It is widely acknowledged that to perform effectively and legitimately, global governance institutions require strong accountability mechanisms. Within multilateralism, accountability rests with the state, as the primary duty-bearer for human rights under international law. As Smita Narula explains, 'The foundational paradigm of international human rights law is the accountability of sovereign states for ensuring the rights of individuals living within their jurisdiction' (Narula 2005: 693). The multi-stakeholder approach that has been promoted by powerful networks not only opens up participation in decision-making processes to other actors, it also raises questions about how accountability is being reconfigured.

There are multiple interpretations of accountability that are reflected in different multi-stakeholder approaches to governance and decision-making. Gleckman (2018) distinguishes between multi-constituency consultations and multi-stakeholder governance. The former, he suggests, work under the authority of nation-states, thereby conforming to the understanding of accountability inherent in international law-that states must be accountable to their publics for their decisions and actions. The latter is autonomous from public governance systems and reflects a different understanding of accountability. While the CFS falls in the category of a multi-constituency consultation process, the UNFSS is emblematic of multi-stakeholder governance that leaves states off the hook.

As the sources of accountability are being re-conceptualized within these settings, other dimensions of food governance become important for providing accountability. For example, for Schedler (1999: 15), accountability relates to answerability and enforcement. Answerability, he suggests, is the right to receive information and the related obligations to share it. This vision of accountability is closely tied to transparency. In the UNFSS, transparency operated to the degree that information was provided to participants about how to participate. However, there was little to no clarity and transparency in terms of how the input from their consultations would be taken up or incorporated, and what the ultimate outcome of the Summit would be. Indeed, throughout the UNFSS this was unclear. Concerns about transparency and accountability led academics participating in Action Track 4, which was dedicated to advancing equitable livelihoods, to approach the UNFSS Secretariat with concerns about governance. The result was the formation of a 'Governance Action Area' in April 2021, in which 67 people participated. However, by August 25, the Chair of the Governance Action Area publicly resigned citing a lack of transparency in decision-making. 
Others suggest that accountability within these new settings should be grounded in robust accountability mechanisms. This approach has been advocated by some academics supporting the Summit (Covic et al. 2021). They argue that it would be important to monitor the outcomes of the UNFSS to ensure that participants are following through with their commitments. This approach views accountability not in terms of the process of decision-making, but rather in the implementation of the Summit's outcomes. This seems to be the vision of accountability inherent in the UNFSS. It has advertised itself as a 'solutions summit', emphasizing its pragmatic role in generating collective engagement and energy to address food systems transformation. As of early October 2021, the Summit had advanced twenty-six 'coalitions', six 'solution-clusters', and registered over 231 'commitments to action'. This dizzying array of solutions and actions are composed of public-private partnerships led by a variety of UN institutions, corporate trade associations, non-governmental organizations, and academics. None of the coalitions have been collectively agreed upon by member states but were voluntarily formed by the UNFSS' 'stakeholders'. With no mandate from states, these coalitions are unaccountable to any publics.

Governance without force requires legitimacy. The UNFSS is seeking to establish a case for legitimacy through a claim at broad-based and unprecedented participation and the framing of the Summit of a 'People's Summit'. It is advancing a model of multi-stakeholder governance backed by powerful actors, while simultaneously bypassing the multilateral spaces where states come together to take decisions. The Secretary-General's final statement to the UNFSS reinforced the vision of legitimacy promoted by the powerful network of actors that lead the UNFSS, with its vague framework of participation and action-centered vision of accountability. With no clear financing mechanisms, no clear role for governmental leadership and limited transparency, it is very likely that the UNFSS solutions that offer investment and profit opportunities will see a larger share of capital and investment, at the expense of other, often community-driven solutions. Embracing this approach to legitimacy is therefore likely to undermine the Summit's own objectives to lead in the transformation of food systems.

\section{Conclusion}

Food systems governance is a dynamic and contested sphere, constituted by competing networks with unequal resources, influence and power. The UNFSS is reshaping global food systems governance and the very foundations of authority and legitimacy in global governance. By replacing multilateralism with multi-stakeholderism, the UNFSS is advancing a vision of food systems governance that sets the foundation for stronger corporate influence both of the UN and food systems at large while simultaneously weakening spaces where movements of the most affected have secured the right to autonomously and collectively organize and participate.

Scholars have long raised concerns that multi-stakeholder summits may be inappropriate for addressing human rights (MSI Integrity 2020). Their concerns stem from the fact that multi-stakeholder governance is premised on voluntary compliance, which undermines international legal frameworks and democratic standards that serve as the foundation of international institutions. In contrast to these standards, the practice of multi-stakeholder governance lacks clear rules and normative grounding. As competing networks develop rival notions of participation and accountability, they are able to shape the practices of multi-stakeholderism in ways that suit their interests. As a result, multi-stakeholder initiatives often serve to mitigate collective action, particularly by civil society and social movements, because accountability for decision-making power is ambiguous. This, in turn, fails to provide the democratic legitimacy necessary for effective governance.

One question that inevitably emerges from the analysis above relates to possible alternatives. In exploring alternatives, we should acknowledge that the history of multilateralism has not yielded more equitable global governance. The politics of multilateralism have been shaped by the structural dependencies of global capitalism combined with elite and undemocratic rule (Getachew 2020). Nonetheless, multilateralism has opened up spaces for transnational agrarian networks to challenge states at local, national, and global levels, drawing on the mechanisms of public accountability to prevent human rights abuses and attempt to transform food and agricultural policies. Food sovereignty actors are keen to maintain these hard-won spaces, calling for an 'inclusive multilateralism' grounded in state accountability, human rights and the active and meaningful participation of those most affected.

In the very short term, questions revolve around the future of the CFS, the best example we have so far of inclusive multilateralism. Some have proposed that the CFS should serve as the main actor to address the UNFSS outcomes. While the CFS is a more accountable governance body, calling on the CFS to lead on FSS solutions puts the CFS in a bind. If the CFS pushes back on adopting the Summit's agenda, the outcomes of the UNFSS are likely to be delegated to less accountable actors and institutions and there is a real risk that the CFS will be deemed less relevant or capable in a changing governance architecture. If the CFS does 'provide support to the follow-up to the FSS ... where appropriate' as stated in the Statement of Action by the UN SecretaryGeneral, the private sector and philanthropic organizations would need to engage in the CFS through the established 
mechanisms for participation. This could help to re-balance power relations following the rules and framework of the CFS. This is also a key reason why it is unlikely that private sector-led initiatives will deem the CFS an appropriate forum for follow-up. However, if the CFS accepts the outcomes of the UNFSS, it also risks de-legitimizing its own processes. Adopting the agenda of the UNFSS would effectively bypass the CFS' own system of democratic agenda-setting, leading it to take on 'solutions' that have been framed a priori by the UNFSS organizers. Ultimately, the CFS would be legitimizing a governance process that actively undermines its own legitimacy.

The tensions raised in this article lead to two key sets of questions for future research and reflection. With respect to the reconfiguration of food systems governance: How are legitimacy and power being re-imagined, reconfigured and contested in the post-UNFSS governance architecture? What types of mechanisms can ensure more equitable and inclusive participation in food systems governance? Which voices need to be prioritized and how? Whose voices need to be limited or even removed? How can power be effectively addressed in multi-stakeholder processes?

When it comes to designing and implementing more equitable governance processes capable of integrating various food system dimensions, we ask: If food systems governance requires more integration of economic, social, and cultural considerations, how can more effective linkages be made to other governance fora (climate, finance, health, trade and biodiversity)? How do we ensure that normative processes coordinated at the global level are translated to regional, national and local contexts?

The paradox of governance is that it is both a key contributor to food system challenges and a key part of any solution. Addressing these questions is critical for supporting the transformations that are urgently needed for more sustainable, just, rights-based and gender transformative food systems.

\section{References}

Anderson, Colin R., and Chris Maughan. 2021. 'The Innovation Imperative': The Struggle Over Agroecology in the International Food Policy Arena. Frontiers in Sustainable Food Systems. https://doi. org/10.3389/fsufs.2021.619185.

Andrée, Peter, Jill K. Clark, Charles Z. Levkoe, and Kristen Lowitt. 2019. Civil Society and Social Movements in Food System Governance. New York: Routledge.

Baiocchi, Gianpaolo and Ernesto Ganuza. 2016. Popular Democracy: The Paradox of Participation. Stanford: Stanford University Press.

Béné, Christophe, Peter Oosterveer, Lea Lamotte, Inge D. Brouwer, Stef de Haan, Steve D. Prager, Elise F. Talsma, and Colin K.Khoury. 2019. When Food Systems Meet Sustainability - Current Narratives and Implications for Actions. World
Development 113 (January): 116-130. https://doi.org/10.1016/j. worlddev.2018.08.011.

Blay-Palmer, Alison. 2012. Imagining sustainable food systems: Theory and practice. Ashgate Publishing, Ltd.

Brem-Wilson, Josh. 2015. Towards Food Sovereignty: Interrogating Peasant Voice in the United Nations Committee on World Food Security. The Journal of Peasant Studies 42 (1): 73-95. https:// doi.org/10.1080/03066150.2014.968143.

Bruno, Kenny, and Joshua Karliner. 2002. Earthsummit. Biz: The Corporate Takeover of Sustainable Development. Food First Books.

Brons, Anke, and Otto Hospes. 2016. Food System Governance: A Systematic Literature Review. In Food Systems Governance, ed. by Amanda Kennedy, Jonathan Liljeblad, 13-42. Routledge.

Canfield, Matthew. 2021. Transnational Food Law. In The Oxford Handbook of Transnational Law. Oxford Handbooks, ed. by Peer Zumbansen. New York: Oxford University Press.

Claeys, Priscilla. 2015. Human Rights and the Food Sovereignty Movement: Reclaiming Control. New York: Routledge.

Claeys, Priscilla, and Jessica Duncan. 2019a. Food Sovereignty and Convergence Spaces. Political Geography 75 (November): 102045. https://doi.org/10.1016/j.polgeo.2019.102045.

Claeys, Priscilla, and Jessica Duncan. 2019b. Do We Need to Categorize It? Reflections on Constituencies and Quotas as Tools for Negotiating Difference in the Global Food Sovereignty Convergence Space. The Journal of Peasant Studies 46 (7): 1477-1498. https://doi.org/10.1080/03066150.2018.1512489.

Claeys, Priscilla, and Marc Edelman. 2019. The United Nations Declaration on the Rights of Peasants and Other People Working in Rural Areas. The Journal of Peasant Studies 47 (1): 1-68. https://doi.org/10.1080/03066150.2019.1672665.

Clapp, Jennifer, Martin Cole, and Thanawat Tiensin. 2021. Opinion: Why Reinvent the Wheel on Food Security and Nutrition? Devex. 21 May. https://www.devex.com/news/sponsored/ opinion-why-reinvent-the-wheel-on-food-security-and-nutri tion-99929.

Clapp, Jennifer, and Sophia Murphy. 2013. The G20 and Food Security: A Mismatch in Global Governance? Global Policy 4 (2): 129-138. https://doi.org/10.1111/1758-5899.12039.

Clark, Michael A., Nina G. G. Domingo, Kimberly Colgan, Sumil K. Thakrar, David Tilman, John Lynch, Inês. L. Azevedo, and Jason D. Hill. 2020. Global Food System Emissions Could Preclude Achieving the $1.5^{\circ}$ and $2 \mathrm{C}$ Climate Change Targets. Science 370 (6517): 705-708. https://doi.org/10.1126/science.aba7357.

Covic, Namukolo, Achim Dobermann, Jessica Fanzo, Spencer Henson, Mario Herrero, Prabhu Pingali, and Steve Staal. 2021. All Hat and No Cattle: Accountability Following the UN Food Systems Summit. Global Food Security 30 (September): 100569. https:// doi.org/10.1016/j.gfs.2021.100569.

Duncan, Jessica. 2015. Global Food Security Governance: Civil Society Engagement in the Reformed Committee on World Food Security. New York: Routledge.

Duncan, Jessica, and Priscilla Claeys. 2018. Politicizing Food Security Governance through Participation: Opportunities and Opposition. Food Security 10 (6): 1411-1424. https://doi.org/10.1007/ s12571-018-0852-x.

FAO, Ifad, UNICEF, WFP and WHO. 2020. The State of Food Security and Nutrition in the World 2020 Transforming Food Systems for Affordable Healthy Diets. Rome: FAO.

Fakhri, Michael. 2021. Interim Report of the Special Rapporteur on the Right to Food. A/76/237. New York: United Nations. https:// documents-dds-ny.un.org/doc/UNDOC/GEN/N21/208/03/PDF/ N2120803.pdf?OpenElement.

Fears, Robin, and Claudia Canales. 2021. The Role of Science Technology and Innovation for Transforming Food Systems Globally. Food Systems Summit Brief Prepared by Research Partners of the 
Scientific Group for the Food Systems Summit. https://doi.org/10. 48565/scfss2021-q703.

Getachew, Adom. 2020. Worldmaking After Empire: The Rise and Fall of Self-Determination. Princeton: Princeton University Press.

Gleckman, Harris. 2018. Multistakeholder Governance and Democracy: A Global Challenge. New York: Routledge.

Haas, Peter M. 1992. Introduction: Epistemic Communities and International Policy Coordination. International Organization 46 (1): 1-35. https://doi.org/10.1017/S0020818300001442.

Haas, Peter M. 2015. Epistemic Communities, Constructivism, and International Environmental Politics. New York: Routledge.

Henkel, H., and R. Stirrat. 2001. Participation as Spiritual Duty; Empowerment as Secular Subjection. In Participation: The New Tyranny?, ed. by Bill Cooke and Uma Kothari: 168-184. London: Zed Books.

HLPE. 2020. Food Security and Nutrition: Building a Global Narrative towards 2030. A Report by the High Level Panel of Experts on Food Security and Nutrition of the Committee on World Food Security. Rome.

Jongen, Hortense, and Jan Aart Scholte. 2021. Legitimacy in Multistakeholder Global Governance at ICANN. Global Governance: A Review of Multilateralism and International Organizations 27 (2): 298-324. https://doi.org/10.1163/19426720-02702004.

Kalibata, Agnes. 2021. Eager for Ambition - All Stakeholders Encouraged to Continue Stepping Forward through the Food Systems Summit with Leadership and Bold Action. New York: Food Systems Summit.https://www.un.org/en/food-systems-summit/news/ eager-ambition-\%E2\%80\%93-all-stakeholders-encouraged-conti nue-stepping-forward-through

Kneen, Brewster. 1989. From land to mouth: Understanding the food system. Toronto: NC Press.

Kennedy, Amanda, and Jonathan Liljeblad. 2016. Food Systems Governance: Challenges for Justice. Equality and Human Rights: Routledge.

Lagerspetz, Eerik. 2015. Democracy and the All-Affected Principle. Res Cogitans 10(1): 6-23.

Margulis, Matias E. 2017. The Global Governance of Food Security. In Palgrave Handbook of Inter-Organizational Relations in World Politics, ed. Joachim A. Koops and Rafael Biermann, 503-525. London: Palgrave Macmillan. https://doi.org/10.1057/978-1-13736039-7_24.

Margulis, Matias E., and Jessica Duncan. 2016. Global Food Security Governance. In Critical Perspectives in Food, ed. by Mustafa Koc, Jennifer Sumner, and Anthony Winson, 270-295. Toronto: Oxford University Press.

Martínez-Torres, María Elena., and Peter M. Rosset. 2014. Diálogo de Saberes in La Vía Campesina: Food Sovereignty and Agroecology. The Journal of Peasant Studies 41 (6): 979-997. https://doi. org/10.1080/03066150.2013.872632.

McKeon, Nora. 2015. Food Security Governance: Empowering Communities, Regulating Corporations. New York, NY: Routledge.

Montenegro de Wit, Maywa, Matthew Canfield, and Alastair Iles. 2021. Weaponizing Science in Global Food Policy. Inter Press Service. 25 June. https://www.ipsnews.net/2021/06/weaponizing-scien ce-global-food-policy/.
MSI Integrity. 2020. Not Fit-for-Purpose: The Grand Experiment of Multi-Stakeholder Initiatives in Corporate Accountability, Human Rights and Global Governance. https://www.msi-integrity.org/wpcontent/uploads/2020/07/MSI_Not_Fit_For_Purpose_FORWE BSITE.FINAL_.pdf.

Narula, Smita. 2005. Right to Food: Holding Global Actors Accountable under International Law. The Columbia Journal of Transnational Law 44: 691.

Narula, Smita. 2010. Reclaiming the Right to Food as a Normative Response to the Global Food Crisis. Yale Human Rights \& Development Law Journal 13: 403.

Parfitt, Trevor. 2004. The Ambiguity of Participation: A Qualified Defence of Participatory Development. Third World Quarterly 25 (3): 537-555. https://doi.org/10.1080/0143659042000191429.

Recine, Elisabetta, Ana Maria Suárez Franco, and Colin Gonsalves. Forthcoming. The Emergence of the 'Food Systems' Discourse and Corporate Solutions To Hunger And Malnutrition. Edited by FIAN International. Right to Food and Nutrition Watch 2021.

Schedler, Andreas. 1999. Conceptualizing Accountability. In The SelfRestraining State: Power and Accountability in New Democracies, ed. by Andreas Schedler, Larry Jay Diamond, Marc F. Plattner. Vol. 14. London: Lynne Rienner.

Sending, Ole Jacob. 2015. The Politics of Expertise: Competing for Authority in Global Governance. Ann Arbor, Michigan: University of Michigan Press.

Shaw, D. John. 2007. World Food Security: A History Since 1945. New York: Palgrave Macmillan.

Suchman, Mark C. 1995. Managing Legitimacy: Strategic and Institutional Approaches. Academy of Management Review 20 (3): 571-610. https://doi.org/10.5465/amr.1995.9508080331.

Turnhout, Esther, Jessica Duncan, Jeroen Candel, Timo Y. Maas, Anna M. Roodhof, Fabrice DeClerck, and Robert T. Watson. 2021. Do We Need a New Science-Policy Interface for Food Systems? Science 373 (6559): 1093-1095. https://doi.org/10.1126/science. abj5263.

von Braun, Joachim, Kaosar Afsana, Louise O. Fresco, and Mohamed Hassan. 2021a. Food Systems: Seven Priorities to End Hunger and Protect the Planet. Nature 597: 28-30. https://doi.org/10.1038/ d41586-021-02331-x.

von Braun, Joachim, Kaosar Afsana, Louise Fresco, Mohamed Hassan, and Maximo Torero. 2021b. Food Systems-Definition, Concept and Application for the UN Food Systems Summit. A Paper from the Scientific Group of the UN Food Systems Summit.

Wezel, A., T. Stéphane Bellon, Charles A. Dore, Dominique Vallod Francis, and Christophe David. 2009. Agroecology as a science, a movement and a practice. A Review. Agronomy for Sustainable Development 29 (4): 503-515. https://doi.org/10.1051/agro/20090 04.

Publisher's Note Springer Nature remains neutral with regard to jurisdictional claims in published maps and institutional affiliations. 